\title{
AN APPROACH TO THE IMPLEMENTATION OF INTERNATIONAL LEGAL INSTRUMENTS IN THE AREA OF CONTROL OVER ADMINISTRATION
}

\author{
Izv. prof. dr. sc. Blerton Sinani*
}

\author{
UDK: 35.07.1(4)EU \\ https://doi.org/10.30925/zpfsr.41.2.10 \\ Ur.: 21. veljače 2019. \\ Pr.: 30. svibnja 2019. \\ Stručni rad
}

\begin{abstract}
Summary
In all states governed by the rule of law the administration is subject to the law and supervision by the courts on the same basis as any individual/citizen, in accordance with the principle of the supremacy of the law. The author only represents the most important instruments in the field of international law concerning control over administration, which supervise the implementation of human rights in the country that has ratified the respective instruments. Therefore, the ratification and incorporation of international normative legal instruments in the form of conventions, such as the European Convention on Human Rights within the national legal order, impose the obligation for a certain state to respect or protect the rights guaranteed by the respective Convention, as well as the case-law of the European Court of Human Rights that governs the interpretation and proper application of the Convention, the relevant European Court of Human Rights case-law setting standards for assessing the efficiency and effectiveness of public administration. Hence, this case law should act as a guideline for improving legal regulations and, under certain circumstances, avoiding the initiation of an administrative dispute before competent national courts, if objectively possible. However, due to certain reasons which will be elaborated upon in this paper, some deviations can occur and, for that matter, judicial review means review by courts of administrative action with a view to ensuring their legality as well as providing the protection and realization of the rights and legal interests of citizens in the sphere of administrative law.
\end{abstract}

Keywords: international law; control; administration; human rights.

\section{INTRODUCTION}

Taking in consideration the broad spectrum of international legal instruments within the area of control over administration and overall in the area of administrative

* Blerton Sinani, Ph.D., Associate Professor, South East European University of Tetovo, Faculty of Law; blerton.sinani@seeu.edu.mk. 
law, particular international standards and instruments will be elaborated and summarized in this article. First, we will begin with the European Convention on Human Rights (ECHR); the International Covenant on Civil and Political Rights (ICCPR); the American Convention on Human Rights (ACHR); the African Charter on Human and Peoples Rights (African Charter) and last but not least, the recommendations of the Council of Europe.

Administrative procedure requires common European regulation by all means, as this is that special field of law by which the administrative body directly meets the citizens. Because of that reason, we need to have good administration ${ }^{1}$ that will respect the rights of individuals and it will be obliged to act upon the signed and ratified conventions and the recommendations of the Council of Europe (COE). Aside from the above mentioned crucial international legal instruments which are being implemented in the field of control over administration, there are other documents that establish international legal standards in the area of administrative law. Those are the recommendations of the $\mathrm{COE}$ and some of them will be elaborated in this article, as they are relevant to the subject matter. With the recommendations of the COE being summarized within the universal legal principles common for the member states, as well as non-binding ("soft" law sources, so they do not fall under the judicial control of the administration), they simultaneously represent standards that the COE considers as important and valuable in certain areas. Having in mind the meaning of administrative-judicial protection for the rule of law, it can be argued that the degree of compliance of certain rights with these recommendations, it is a barometer of democracy of the particular society and state.

In the area of administrative law, the Committee of Ministers of the COE has adopted a number of recommendations, giving though to the purpose of the COE to achieve 'greater unity' among its members, ${ }^{2}$ while the European Court of Human Rights (ECtHR) delivers judgments and at the same time establishes standards regarding administrative law through its case-law. The practice of the ECtHR for the member States of the COE should act as a guideline for improving legal regulations and, under certain circumstances, avoiding the initiation of an administrative dispute before a competent court, if possible. The COE, in many occasions, has adopted recommendations that refer to the judicial control of the administration in order to define minimum standards which all member states of the COE should accept, considering the differences of their legal systems. Hence, promoting these standards and their practical implementation cannot be possible without a functioning system

1 Good administration means that "administrative bodies have a duty to exercise the powers and responsibilities vested in them by existing laws and regulations. In other words, not only must they avoid any unfair doctrinal approach but they must also endeavor to adapt the legal rules to social and economical realities. Theodore Fortsakis, "Principles governing good administration", European Public Law 11, no. 2 (2005): 207.

2 Statute of the Council of Europe (1949), approached July 23 2020, https://www.coe.int/en/ web/conventions/full-list/-/conventions/treaty/001. Article 1(a) stipulates the following: "The aim of the Council of Europe is to achieve a greater unity between its members for the purpose of safeguarding and realizing the ideals and principles which are their common heritage and facilitating their economic and social progress". 
of administrative justice, which allows private persons to effectively challenge administrative acts as individual decisions and holds public authorities accountable for breaches of law and infringements of human rights. Insofar, the implementation of the rights contained within the conventions and recommendations is not at its satisfactory level, due to the increased number of applications submitted to the ECHR, mainly for the probable violation of the right to a fair trial in administrative proceedings contained in Article 6(1) of the ECHR.

\section{RIGHT TO A FAIR TRIAL IN THE AREA OF ADMINISTRATIVE JUSTICE}

Administration of justice is a broad term that includes the norms, institutions, and frameworks by which states seek to achieve fairness and efficiency in dispensing justice: criminal, administrative and civil. ${ }^{3}$ Judicial review of administrative action represents the power of the courts to examine the legality of the administrative acts and, thereby, to safeguard the citizen's rights in the domain of administrative law. The underlying object of judicial review is to ensure that the authority does not abuse its power and the individual receives just and fair treatment and not to ensure that the authority reaches a conclusion, which is correct in the eyes of the law. The role of judiciary in protecting the citizens against the excess of officials has become all the more important with the increase in the powers and discretion of the public officials in the modern welfare states. ${ }^{4}$ As already indicated, in the beginning of this paper, we will focus on the fairness and efficiency of justice in administrative matters. The rules applicable to the administration of justice are extensive and refer to, inter alia, fair trial, independence and impartiality of the tribunal, and the right to a legal remedy. These rules are contained in many global and regional treaties/conventions that set the postulates for protection of the basic and guaranteed human rights and freedoms. The right to a fair trial which does not focus on a singles issue, but rather consists of a complex set of rules and practices, has been elaborated and guaranteed by many global and regional human rights treaties starting with the UDHR (Universal Declaration of Human Rights). In 1948, the UN General Assembly adopted the UDHR ${ }^{5}$ where Article 10 states that: "Everyone is entitled in full equality to a fair and public hearing by an independent and impartial tribunal, in the determination of his rights and obligations and of any criminal charge against him". Following the adoption of the UDHR, the UN Commission on Human Rights ${ }^{6}$ drafted the rights contained in ICCPR, ${ }^{7}$ where

3 David Weissbrodt, "The Administration of Justice and Human Rights", University of Hong Kong Law Review, no. 1 (2009): 23, https://scholarship.law.umn.edu/cgi/viewcontent. cgi?article $=1245 \&$ context $=$ faculty_articles.

4 Awal Hossain Mollah, "Judicial Control over Administration and Protect the Citizen's Rights: An Analytical Overview", (2006): 9, https://www.researchgate.net/publication/320442968.

5 Universal Declaration of Human Rights, UN General Assembly resolution 217A, 10 December, 1948. Approached July 23 2020, https://www.un.org/en/universal-declaration-human-rights/.

6 The United Nations Commission on Human Rights which ceased to exist in 2006.

7 International Covenant on Civil and Political Rights, UN General Assembly resolution 2200A (XXI), December 16, 1966, entered into force March 23, 1976. Approached July 232020 
Article 14(1) specifically provides for equality before the courts and for the right to a fair and public hearing by a competent, independent and impartial tribunal established by law, regardless of whether a criminal trial or a suit at law is involved. Wording of Article 14 (1) emphasizes that: "All persons shall be equal before the courts and tribunals. In the determination of any criminal charge against him, or of his rights and obligations in a suit at law, everyone shall be entitled to a fair and public hearing by a competent, independent and impartial tribunal established by law. The press and the public may be excluded from all or part of a trial for reasons of morals, public order (ordre public) or national security in a democratic society, or when the interest of the private lives of the parties so requires, or to the extent strictly necessary in the opinion of the court in special circumstances where publicity would prejudice the interests of justice...".

An analogue definition of the right to a fair trial and right to be tried within a reasonable amount of time by an impartial tribunal can be found in the African Charter (which is interpreted and applied inter alia by the African Commission on Human and People's Rights as a quasi-judicial body, which does not carry out judicial review as such. $)^{8}$ where Article 7(1) stipulates the following: "Every individual shall have the right to have his cause heard. This comprises: a) the right to an appeal to competent national organs against acts of violating his fundamental rights as recognized and guaranteed by conventions, laws, regulations and customs in force; b) the right to be presumed innocent until proved guilty by a competent court or tribunal; c) the right to defence, including the right to be defended by counsel of his choice; d) the right to be tried within a reasonable time by an impartial court or tribunal". Taking this provision into account, from its extensive interpretation it is obvious that 'the protection of the rights' also extends to administrative matters. However, this interpretation in respect of administrative matters covers the right to appeal to national organs against acts of violations and among other rights, the right to be tried within a reasonable amount of time by an impartial and court or tribunal. Insofar, the practice and the jurisprudence of competent international courts have proven that these rights are the most inflicted and violated in regards to administrative proceedings.

The last regional standard concerning the judicial control on administration and protection of the right to a fair trial and hearing within a reasonable amount of time before an independent and impartial tribunal, elaborated in this paper is the American Convention on Human (the ACHR is interpreted and applied by the Inter-American Court of Human Rights). ${ }^{9}$ Namely, Article 8(1) of ACHR prescribes that: "Every person has the right to a hearing, with due guarantees and within a reasonable time, by a competent and independent, and impartial tribunal, previously established by law,

https://www.ohchr.org/en/professionalinterest/pages/ccpr.aspx.

8 African Charter on Human and Peoples Rights Nairobi 1981 and entered into force in October 1986. Approached July 232020 https://treaties.un.org/doc/Publication/UNTS/Volume\%20 1520/volume-1520-I-26363.

9 American Convention on Human Rights "Pact of San Jose, Costa Rica" (b-32), Organization of American States, adopted on 22 November 1969 and entered into force in 18 July 1978. Approached July 232020 https://www.oas.org/dil/treaties_B-32_American_Convention_on_ Human_Rights_sign.htm 
in the substantiation of any accusation of a criminal nature made against him or for the determination of his rights and obligations of a civil, labour, fiscal, or any other nature". In this provision, the scope of the right to a fair trial is rather broad, since it applies to rights and obligations of civil, labour, fiscal or any other nature.

Concerning Europe, the most significant legal act guaranteeing human rights and developing further the system of their protection is the ECHR adopted in 1950 within the COE. Article 6 (paragraph 1) of the ECHR in the part relating to the right to a trial within a reasonable time (as one of the elements of the right to a fair trial) introduces a factor of time as an important requirement for the exercise of justice. As lengthy court proceedings might jeopardize the effectiveness and credibility of the judiciary, the Convention emphasizes the importance of rendering justice without delay, stipulating that judicial proceedings must be completed within a reasonable time. $^{10}$

\subsection{Importance of the trial within a reasonable time}

There is no doubt that legal protection needs effectiveness. However, completely clear criteria for defining and assessing the effectiveness or efficiency of a particular legal system has not been established yet. Legal protection that remains declarative and lacks effectiveness cannot justify its existence because it does not fulfill the purpose for which it has been established. Therefore, the system of procedural rights referred to in Article 6 of the Convention is based on a notion of effective legal protection which does not exist if it is not timely. The purpose of Article $6 \S 1$ of the Convention in its part guaranteeing a trial within a reasonable time is to protect the parties to civil and criminal proceedings from excessive delays in proceedings and to stress the importance of rendering justice without delays which might jeopardize the effectiveness and credibility of the judicial systems. Every legal order founded on the principles of a legal state and the rule of law seeks to achieve as efficient as possible system of protection of civil and human rights. Not only is the decision made within a reasonable time in the interest of a person applying to a court to decide on his or her rights or obligations, or suspicion of a criminal offence or a criminal charge, but it is also in the interest of legal certainty as the principle underlying an objective legal order which is why that principle should become imperative in each country aspiring to attain the ideal of the rule of law. The trial within a reasonable time is closely related to the notion of a fair trial that does not exist in the event of excessively long uncertainty of the parties as to their rights and obligations to be determined by the court. The purpose of the reasonable-time requirement set out in Article $6 \S 1$ of the Convention is to provide a guarantee that a particular case before the court will be completed within a reasonable time, which means that the period of uncertainty and insecurity for the party to the proceedings will be reduced to an acceptable level. Although it may seem that stressing the need for an effective trial is a recent development, the problem of excessive length of court proceedings has been recognized much earlier,

10 Sanja Otočan, Analysis of the Current Legal Framework and Case-Law in Respect of Effective Remedies for the Protection of the Right to a Trial within a Reasonable Time in Administrative Procedures and Administrative Disputes (Podgorica: 2019.), 7. 
so we can find various attempts to reduce the length of the proceedings in the distant past. The importance of effective court proceedings, as one of the most important qualities of legal protection, has been recognized even by Roman jurists, accepting the principle of Ne lites fiant immortales. The attempts to accelerate proceedings continued from the ancient period, through the middle ages to the present day. The criticism of slow court proceedings throughout history can be found even in literature. Legal transactions require an effective trial or a fast termination of disputes, which is why courts must act in accordance with the principle of cost-effectiveness. Efficient justice is of exceptional legal and legal-political importance. It encourages faster and safer capital flows and contributes to a feeling of legal certainty. The principle of cost-effectiveness is indispensable in providing effective judicial protection. A specific monopoly position of state administration bodies and legal entities exercising public powers that make decisions in administrative matters may lead to their abuse of position by delaying the proceedings, i.e. by not making decision on a request. That is the "silence of the administration" - a passive conduct of the administrative body, instead of making a decision on the request from the party. The types and nature of the rights exercised in administrative proceedings before administrative bodies and administrative courts indicate the importance of timely decision-making in administrative matters. The decision to refer a patient to a medical treatment, on child allowance entitlement, on one of social welfare entitlements etc. becomes irrelevant after a certain time since in such cases delayed decision cannot attain the purpose for which the request was submitted. Unlike the administration, courts are not bound by deadlines when deciding the cases, which is why the consequences of the "silence of the judiciary" and of the "silence of administration" are not the same. The "silence of the judiciary" means a situation when the court to which an application for judicial review has been filed has failed to hold a hearing and decide on that application. The failure of the court to decide on a particular application within a time which, in the light of the circumstances of a particular case, can be considered to be reasonable constitutes a violation of the constitutional right to a fair trial and also an infringement of the principle of the rule of law. The ECtHR considers that failure to render a court decision in certain cases of excessively long proceedings can be considered to be a "denial of justice"."

\section{2. "Reasonable time" in the ECtHR case-law}

The Convention does not determine the content of the right to a trial within a reasonable time, so the meaning of the concept of a reasonable time - a legal standard that can be considered as the time necessary to decide on the merits of the application, is determined by the ECtHR through its case-law. The ECtHR does not set specific time-limits on the length of judicial proceedings or general rules in respect of its duration, but it assesses whether the length of the proceedings is reasonable in the light of the circumstances of each individual case. The process is conducted in two

11 Otočan, Analysis of the Current Legal Framework and Case-Law in Respect of Effective Remedies for the Protection of the Right to a Trial within a Reasonable Time in Administrative Procedures and Administrative Disputes, 11. 
steps:

- determining the period to be considered;

- assessing whether the length of the period considered was reasonable.

Despite the fact that the ECtHR has not set universal rules, the ECtHR case-law provides useful information on the ECtHR's approach to assessing the reasonableness of the length of proceedings. Based on the analysis of the relevant case-law of the ECtHR, the European Commission for the Efficiency of Justice summarised the main positions relating to the duration of judicial proceedings in the report "Length of court proceedings in the member states of the COE based on the case law of the ECtHR". The Report mentions, inter alia, that:

- Duration of up to two years at one instance of the trial in non-complex cases is generally regarded as reasonable.

- When proceedings have lasted more than two years at one instance of the trial, the ECtHR examines the case closely to determine whether the national court has shown due diligence in the process.

- In priority cases, it is possible to find violation of the right to a trial within a reasonable time even if the case lasted less than two years.

- In complex cases, the ECtHR may allow time longer than two years, but, generally, it pays special attention to the periods of inactivity which are clearly excessive. The proceedings which lasted more than five years will rarely be assessed as complying with the Convention right to a trial within a reasonable time and the proceedings lasting more than eight years almost never. The only situation in which the ECtHR will not find violation in spite of manifestly excessive duration of proceedings are the cases in which long duration of proceedings is the consequence of the applicant's behaviour. When deciding on the merits of the application, the ECtHR firstly determines the length of the particular judicial proceedings the party alleges that they do not comply with the reasonable-time requirement set out in Article $6 \S 1$ of ECHR. The ECtHR determines the starting point and the end of court proceedings. When examining the duration of the proceedings, the Court considers the total duration of the proceedings, but also whether there were longer periods of inactivity at a certain stage of the proceedings which cannot be attributed to the applicant. Strict limits have not been set, but the ECtHR case-law refers to indicative limits. ${ }^{12}$

\subsection{The criteria for the assessment of the reasonableness of the length of the proceedings}

By considering the specific circumstances of each case in the light of the established criteria for assessing whether the proceedings have been completed within a reasonable time, the ECtHR determines whether there has been a violation of the right to a trial within a reasonable time. The assessment whether in a particular case

12 Otočan, Analysis of the Current Legal Framework and Case-Law in Respect of Effective Remedies for the Protection of the Right to a Trial within a Reasonable Time in Administrative Procedures and Administrative Disputes, 10-13. 
the Convention right to a trial within a reasonable time has been violated depends on a number of factors:

- the total length of the proceedings,

- the complexity of the case,

- the conduct of the domestic authorities,

- the conduct of the applicant - what was at stake for the applicant in the dispute,

- the number of stages of the proceedings - specific circumstances that may justify longer duration of the proceedings. ${ }^{13}$

The various wordings used in the previously elaborated legal provisions have generated uncertainties as to the exact scope of application of the right of access to courts and the right to a fair trial. Hence, these diverse wordings inevitably raise questions on the precise scope of applications of the right to a fair trial. What is exactly meant by civil rights, obligations, and do these provisions apply to administrative law? ${ }^{14}$ The answers to these questions can be found, for instance in the jurisprudence of the ECtHR, where in the case of Reingeisen v. Austria, the court extended the notion of civil rights and obligations, coverings some rights and obligations that could be solved in an administrative procedure. Furthermore, in the case of König v. Germany, concerning the possible violation of Article 6(1), the ECtHR expressed its opinion by stating the following: "If the case concerns a dispute between an individual and a public authority, whether the latter had acted as a private person or in its sovereign capacity, is not conclusive. Only the character of the right at issue is relevant. An activity presenting the character of a private activity cannot automatically be converted into a public-law activity by reason of the fact that it is subject to administrative authorisations and supervision". ${ }^{15}$ In the case of Feldbrugge v. the Netherlands, the ECtHR had to deal for the first time with the issue about social security where a question regarding the applicant's right to a fair hearing by a tribunal was breached in the procedure for determining her right to sickness benefits. There was a genuine and serious dispute concerning this issue and in the end, the court ruled that there was a violation of Article 6(1).$^{16}$ Additionally, in the case of Benthem v. the Netherlands, the ECtHR held that there was a violation of Article 6(1) concerning the right to a fair trial and particularly this case has established what is further known in the international case law as the 'Benthem criteria'. ${ }^{17}$

13 Stevan Lilić, Evropsko upravno pravo, (Beograd: Pravni fakultet Univerziteta u Beogradu, 2011), 104.

14 Piere Schmitt, Access to Justice and International Organizations: The case of Individual Victims of Human Rights Violations, (Belgium: Leuven Centre for Global Governance Studies, 2017), 39.

15 König v. Germany, ECHR, Application no.6232/73, para. 89-91. Approached July 232020 https://hudoc.echr.coe.int/rus\#\{\%22itemid\%22:[\%22001-57511\%22]\}.

16 Feldbrugge v. the Netherlands, ECHR, Application No.8562/79 from 29 May 1986. Approached July 232020 https://opil.ouplaw.com/view/10.1093/law:ihrl/56echr86.case.1/lawihrl-56echr86

17 According to what are known as the Benthem criteria, Article 6 will only be applicable if (a) there is a dispute ('contested') of a serious and legal nature between two (legal) persons which 
From the case law of the Human Rights Committee (HRC) we can emphasize the case of Perterer v. Austria, where according to HRC, the definition of "determination of rights and obligations in a suit at law" is based on the nature of the right in question rather than on the status of one of the parties or the particular forum provided by the domestic legal system for the determination of a particular right. This means that administrative law matters are, in principle, also covered by the scope of Article 14(1) of ICCPR. Examples of administrative law matters that are covered, include termination of employment of civil servants for reasons other than disciplinary, which was ruled by the HRC in the case of Casanovas v. France. ${ }^{18}$ Furthermore, the IACHR and the Inter-American Court of Human Rights have determined that fair trial rights must be observed in all proceedings for the determination of obligations and rights, and that fair trial guarantees are applicable to administrative proceedings, as it was determined in the case of Baena-Ricardo et al. v Panama.${ }^{19}$ Similarly, the African Commission has determined that the right to a fair and public hearing is a general principle applicable to all legal proceedings, including administrative. ${ }^{20}$ The judgments and findings of international and regional courts, commissions and bodies help to interpret and elucidate the meaning of provisions contained in international standards and other instruments. In this way, they are creating an updated and extensive interpretation of the international conventions, depending of the nature of every individual case held before these courts and commissions.

\section{FRAMEWORK OF COUNCIL OF EUROPE RECOMMENDATIONS IN THE AREA OF ADMINISTRATIVE MATTERS}

The COE began its work in the sphere of administrative law quite early, in 1977 when its first resolution on protection of the individual in relation to the acts of administrative authorities was issued..$^{21}$ The ideological basis of the document was the ever-increasing importance of public administrative activities. Public authorities, in addition to their traditional task of safeguarding law and order, have been increasingly

are in some relation to the right; (b) the disputed right has - at least on arguable grounds - been recognised under national law; (c) the outcome of the national proceedings is directly decisive for these rights and obligations; and (d) these rights are 'civil' in the autonomous sense of the convention.

18 Casanovas v France, HRC Communication 441/1990, UN Doc CCPR/C/51/D/441/1990, 26 July 1994. Approached July 232020 http://hrlibrary.umn.edu/undocs/html/vws441.htm.

19 Baena-Ricardo et al. v Panama, Inter-American Court of Human Rights, 2 February 2001, para. 124. Approached July 232020 https://www.corteidh.or.cr/docs/casos/articulos/seriec_72_ ing.

20 For more information see: "Principles and Guidelines on the Right to a Fair Trial and Legal Assistance in Africa", African Commission, DOC/OS(XXX)247, section A - General Principles Applicable to All Legal Proceedings, http://www1.umn.edu/humanrts/research/ZIM\%20 Principles_And_G.pdf

21 Resolution (77) 31 on protection of the individual in relation to the acts of administrative authorities (Adopted by the Committee of Ministers on 28 September 1977 at the 275th meeting of the Ministers' Deputies). Apparoached July 232020 https://rm.coe.int/16804dec56. 
engaged in a vast variety of actions aimed toward ensuring the well-being of the citizens and promoting the social and physical conditions of society. This development resulted in the individual being more frequently affected by administrative procedures. According to the text of the resolution, in spite of the differences between the administrative and legal systems of the member States, there is a broad consensus concerning the fundamental principles that should guide the administrative procedures and particularly the necessity to ensure fairness in the relations between the individual and administrative authorities. ${ }^{22}$

Bearing in mind the need for drafting a recommendation on good administration, the Parliamentary Assembly of COE recommended to the Committee of Ministers to prepare a consolidate model code of good administration, deriving from several recommendations in the area of administrative matters, particularly from recommendation No. (80) 2 and the European Code of Good Administrative Behaviour. ${ }^{23}$ Beside these, two other important recommendations have been used as guidelines in order to prepare the recommendation on good administration. Those are the recommendation on provisional court protection in administrative matters ${ }^{24}$ and recommendation on administrative sanctions..$^{25}$ The closure of this process happened in 2007 when a substantive document had been prepared on good administration, referring to all the other recommendations delivered by the $\mathrm{COE}$ in the field of administrative matters.

According to the text of this recommendation, the preamble underlines that good administration in many situations involves striking an appropriate balance between the rights and interests of those directly affected by state action on the one hand and the protection of the interests of the community at large, in particular those of the weak or vulnerable, on the other, and recognizing that procedures intended to protect the interests of individuals in their relations with the state should in certain circumstances protect the interests of others or the wider community. ${ }^{26}$ Additionally, it has been emphasized that good administration depends on the organization and management

22 See Appendix to Resolution (77) 31: The following principles (such as the right to be heard; access to information; assistance and representation...) apply to the protection of persons, whether physical or legal, in administrative procedures with regard to any individual measures or decisions which are taken in the exercise of public authority and which are of such nature as directly to affect their rights and liberties or interests.

23 What is important about the Recommendation (80)2 is the fact that it contains the basic principles regarding the behavior of administrative authority in exercising a discretionary power. Additionally it elaborates that the general administrative guidelines that govern the exercise of a discretionary power are made public or communicated in an appropriated manner.

24 Recommendation (89) 8 on provisional court protection in administrative matters (adopted by the Committee of Ministers on 13 September 1989 at the $428^{\text {th }}$ meeting of the Ministers" Deputies). Approached July 232020 https://rm.coe.int/16804f288f.

25 Recommendation (91) 1 on administrative sanctions (adopted by the Committee of Ministers on 13 February, 1991 at the $452^{\text {nd }}$ meeting of the ministers' deputies). Approached July 232020 https://rm.coe.int/16804fc94c.

26 For more details see: Recommendation (2007) 7 on good administration (adopted by the Committee of Ministers on 20 June 2007 at the $999^{\text {th }}$ meeting of the Ministers' Deputies. Approached July 232020 https://rm.coe.int/16807096b9. 
and at the same time, it must meet the requirements of effectiveness, efficiency and relevance to the needs of society. Because of this reason, the recommendation contains the principles of good administration, the rules governing administrative decisions and the right to appeal against administrative decisions. ${ }^{27}$ Subsequently, following this recommendation, many others were adopted by the Council of Europe also defining substantial requirements in the field of administrative law.

As regard to the significance and practical impact of the COE recommendations, it is important to observe the following: According to the Statute of the COE (Articles 15b and 20), a recommendation is one of the legal instruments by which the Committee of Ministers communicates its conclusions in respect of its measures that believes will achieve the basic goals of the COE. According to Puppinck, Director of the European Centre for Law and Justice: "A recommendation differs from other methods of communication to governments in that it explicitly indicates an agreement regarding the measures contained therein, irrespective of the legal nature of these measures (convention, agreement, common policy and others). In adopting a recommendation, each State expresses its willingness and the Committee of Ministers expresses its agreements. The legal significance can be assessed in light of (1) existing treaty standards, (2) especially the European Court of Human Rights and its interpretation, (3) domestic law and (40 other international standards being developed". ${ }^{28}$ Furthermore, in respect of the legal status of the recommendations, it must be explained that contrary to conventions that states may have ratified and are obliged to respect them, the situation is completely different regarding the status of recommendations. This means that they do not have a legally binding effect, however, their importance should not be neglected due to the moral and political effect that they have upon states and their governments. Governments, if necessary, can express reservations to all or part of a recommendation, as they can do under Article 10.2, lit. c) of the Rules of Procedure for the meetings of the Ministers' Deputies. Hence, it can be concluded that conventions have legal supremacy over recommendations, especially when they fall within the scope of an existing convention. ${ }^{29}$ Moreover, the member states cannot recommend that governments adopt new measures if they are contrary to an existing convention which they have already signed and obliged to

27 For more information see: Section I, II and III from the Recommendation (2007) 7.

28 Grégor Puppinck, Status of the recommendations of the Committee of Ministers in the legal field of the Council of Europe - Synthesis, (Strasbourg: European Centre for Law and Justice, 2012.), 1.

29 In this connotation, one question arises and that is: Should the European Union (EU) accede to the Council of Europe's ECHR? These past years, it has been discussed about the accession issue and there is a point of view that EU accession to the ECHR will not affect the division of powers between the EU and its member states provided for in the Treaties. Contrary, accession will allow the EU to become a party in cases directly or indirectly concerned with Community law before the ECHR. The binding effects on the EU of any decision by the Court that the ECHR has been violated will also be strengthened, and the execution of judgments by the EU will be guaranteed. Even more, the collaboration between Council of Europe and EU can be seen through the Council of Europe reports, recommendations which are constantly consulted by EU institutions and working groups dealing with issues relating to Council of Europe member states. 
respect it. On the contrary, it would mean infringement of international norms and undertaken obligations to respect them. Hence, it must be argued from the Strasbourg law case that there is an interpretation of the ECHR provisions in the light of the recommendations of the Committee of Ministers. This was clearly expressed in the case of Demir and Baykara v. Turkey (ECHR Application No.34503/97). Namely, the ECHR asserted the following: "in defining the meaning of terms and notions in the text of the convention, can and must take into account elements of international law other than the convention, the interpretation of such elements by competent organs, and the practice of European States reflecting their common values. The consensus emerging from specialised international instruments and from the practice of contracting states may constitute a relevant consideration for the court when it interprets the provisions of the convention in specific cases". ${ }^{30}$ Additionally, the ECtHR has developed the doctrine of the effectiveness of rights and has evolved an interpretation according to which "the convention is intended not to guarantee rights that are theoretical or illusory but rights that are practical and effective". ${ }^{31}$

\subsection{Issues about judicial and other (alternative) ways of resolution of administrative disputes}

Recommendation (2001) 9 of the Committee of Ministers on alternatives to litigation between administrative authorities and private parties ${ }^{32}$ promotes the use of alternative means for solving disputes in accordance with the principle of good practice. The purpose of this recommendation is to easily overcome and to undergo a rigid or punctilious solution in relation to dispute settlement before the court, which is, by rule, overloaded and often burdened with the rigidity of the procedure. According to the recommendation, the alternative means are: internal views, conciliation, mediation, negotiated settlement and arbitration, and what is common for all of them are their non-binding character. ${ }^{33}$ Moreover, internal views, in principal, should be possible in relation to any act. They may concern the expediency and/or legality of an administrative act. Conciliation and mediation can be initiated by the parties, a

30 For more details see: para. 86 of the case Demir and Baykara v. Turkey (ECtHR Application No.34503/97). Approached July 232020 https://hudoc.echr.coe.int/ tur\#\{\%22itemid\%22:[\%22001-89558\%22]\}. Subsequently it is not necessary for the respondent State to have ratified the entire collection of instruments that are applicable in respect of the precise subject matter of the case concerned. It will be sufficient for the court that the relevant international instruments denote a continuous evolution in the norms and principles applied in international law or in the domestic law of the majority of member states of the Council of Europe.

31 See: Artico v. Italy, ECHR Application No. 6694/74, para. 33. Approached July 232020 https:// www.dipublico.org/1887/case-of-artico-v-italy-european-court-of-human-rights.

32 Recommendation (2001) 9 on alternatives to litigation between administrative authorities and private parties (adopted by the Committee of Ministers in 5 September 2001 at the $762^{\text {nd }}$ meeting of the Ministers' Deputies). Approached July 232020 https://rm.coe.int/16805e2b59

33 Alternative means to litigation should be either generally permitted or permitted in certain types of cases deemed appropriate, in particular those concerning individual administrative acts, contracts, civil liability and generally speaking claims relation to a sum of money. 
judge or compulsory by law. In rare situations and unless otherwise provided by law, administrative authorities shall not use a negotiated settlement to disregard their obligations. Finally, arbitration is the process where parties should be able to choose the law and procedure for the arbitration within the limits prescribed by law. Moreover, arbitrators should be able to review the legality of an act as a preliminary issue with the purpose of reaching a decision on the behalf of merits even if they are not authorized to rule on the legality of an act with a view to it being quashed. ${ }^{34}$

The issue concerning the resolution of disputes before courts has been solved by recommending the use of these alternative means even during the court proceeding. The member states of the COE are encouraged to devote themselves to alternative ways of resolving disputes. Affirmation of alternative means is specifically emphasized in the area of criminal and family law. Over the last ten years, a lot of attention is devoted to some alternatives of administrative trials. The development of alternative means for solving disputed conflicts between the administration and private entities largely depends on two factors. The first one is characteristic for states that do not have sufficiently developed courts for solving administrative disputes. The later one is an expression of the necessity of the citizens for more flexible and faster resolution of administrative disputes. The most important factor, which must be stressed out, is the fact that alternative means have been used before the courts in order to avoid this practice. Meanwhile, in the Preamble, it is emphasized that the resolution of disputes before the court is still necessary and that the alternative means represent a supplement rather than a substitution for judicial control. Indeed, it can be concluded that in many countries alternative means of administrative dispute resolution have not been used in their full capacity, so certainly there is a necessity for their further affirmation with a final purpose of broader acceptance.

Contrary to the alternatives to litigation between administrative authorities and private parties, Recommendation (2004) 20 of the Council of Europe ${ }^{35}$ elaborates the issue about judicial review of administrative acts. Namely, taking the main purpose of the COE into account, which is to 'achieve greater unity among member States', it has been considered that the judicial review of administration acts represents an essential element in the system of the protection of basic human rights and freedoms and should provide an open approach for this aspect of revision as such. Additionally, this recommendation recalls Article 6 of the ECHR which provides that "everyone is entitled to a fair and public hearing within a reasonable time by an independent and impartial tribunal established by law" and the relevant case-law on administrative disputes of the ECtHR considering that effective judicial review of administrative acts to protect the rights and interests of individuals is an essential element of the system of protection of human rights. ${ }^{36}$

34 See: Section 3 - Special features of each alternative means of the Recommendation (2001) 9. Approached July 232020 https://rm.coe.int/16805e2b59.

35 Recommendation (2004) 20 on judicial review of administrative matters (adopted by the Committee of Ministers on 15 December, 2004 at the $909^{\text {th }}$ meeting of the Ministers' Deputies). Approached July 232020 https://rm.coe.int/CoERMPublicCommonSearchServices/ DisplayDCTMContent?documentId $=09000016805 \mathrm{db} 3 \mathrm{f} 4$.

36 See: Preamble of Recommendation (2004) 20. Furthermore, in this connotation it must be 
For the needs of the recommendation, the term 'administrative acts' has been expanded and additionally covers the legal acts (both individual and normative) and situations of refusal to act or an omission to do so in cases where the administrative authority is under an obligation to implement a procedure following a request. In this connotation, by 'judicial review' the examination and determination by a tribunal of the lawfulness of an administrative act and the adoption of appropriate measures is meant, with the exception of reviews by a constitutional court. Hence, according to the above written definition, the scope of judicial review should be all administrative acts and such review may be direct or by way of exception. ${ }^{37}$ In judicial review, the court does not go into the merits of the administrative action; the courts function is restricted to ensure that such authority does not act in excess of its power. The court is not supposed to substitute its decisions for that of the administrative authority. In judicial review of administrative action, the courts merely enquire whether the administrative authority has acted according to the law. ${ }^{38}$ Subsequently, judicial review should be available at least to natural and legal persons in respect of administrative acts that directly affect their rights or interests. Member States are encouraged to examine whether access to judicial review should not be opened to associations or other persons and bodies empowered to protect collective or community interests as well. Besides, the most crucial aspect is the way of regulation of the judicial review. It should be conducted by a tribunal established by law whose independence and impartiality are guaranteed in accordance with the terms of Recommendation (94) 12. Contrary, the whole process could be jeopardized if there is a lack of these judicial standards. ${ }^{39}$

Finally, there is the issue about effectiveness of judicial review. If a tribunal finds that an administrative act is unlawful, it should have the powers necessary to redress the situation so that it is in accordance with the law. In particular, it should be competent at least to quash the administrative decision and, if necessary, to refer the case back to the administrative authority to take a new decision that complies with

emphasized the need to achieve balance between the legitimate interests of all parties with a view to providing for the procedure without delay and for efficient and effective public administration.

37 See Section B - Principles and scope of judicial review of the Recommendation (2004) 20.

38 Judicial review also concerns two important questions: Whether the authority has exceeded its power? And whether has abused its power? For more details see: Chapter 2 - "Judicial Review of Administrative Action", 24; http://shodhganga.inflibnet.ac.in/bitstream/10603/38174/8/08 chapter\%202.pdf.

39 See: Recommendation on the independence, efficiency and role of judges, (adopted by the Committee of Ministers on 13 October, 1994 at the $518^{\text {th }}$ meeting of Ministers' Deputies. Approached July 232020 https://www.ohchr.org/EN/Issues/Education/ Training/Compilation/Pages/12RecommendationNoR(94)12toMemberStatesonthe Independence,EfficiencyandRoleofJudges(1994).aspx According to the general principles of the recommendation: "The independence of judges should be guaranteed pursuant to the provisions of the convention and constitutional principles, for example by inserting specific provisions in the constitutions or other legislation or incorporating the provisions of this recommendation in internal law". Further, in the decision-making process, judges should be independent and be able to act without any restriction, improper influence, inducements, pressures, threats or interferences, direct or indirect, from any quarter or for any reason. 
the judgment. ${ }^{40}$

\subsection{Execution of administrative and judicial decisions in the field of administrative law}

Decisions of administrative authorities that entail obligations for private persons and judicial decisions in the field of administrative law and recognize rights for private persons should be executed. This obligation is contained in Recommendation (2003) 16 of the $\mathrm{COE}^{41}$ whose purpose is the efficient execution of administrative and judicial decisions in the field of administrative law by handling an effective system of voluntary execution, as well as establishing a system of fairly execution. Subsequently, member states should provide an appropriate legal framework to ensure that private persons comply with administrative decisions that have been brought to their knowledge in accordance with the law, notwithstanding the protection by judicial authorities of their rights and interests. The introduction of an appeal against a decision entails automatic suspension; private persons should be able to request an administrative/judicial authority to suspend the implementation of the contested decision in order to ensure the protection of their rights and interests. ${ }^{42}$

Deciding on the request for suspension, the public interest and the rights and interests of third persons should be taken into account by the administrative authority and, unless it is excluded by law, by the judicial authority. However, in the procedure of enforcement, the administrative authorities should accept the following guarantees: enforcement must be expressly provided by the law; private persons should be given the possibility to comply with the administrative decision within a reasonable amount of time; the use of and the justification for enforcement are to be brought to the attention of the private persons against whom the decision is to be enforced and the enforcement measures used including any accompanying sanctions are to respect the principle of proportionality. ${ }^{43}$

Member states should ensure that administrative authorities implement judicial decision within a reasonable period of time and in order to give full effect to these decisions, they should take all necessary measures in accordance with the law. However, in cases of non-implementation by an administrative authority of a judicial decision, an appropriate procedure should be provided in order to seek execution of that decision, particularly through an injunction or a coercive fine. Furthermore, Recommendation (2003) 16 prescribes that it is an obligation of the member states to ensure that administrative authorities will be held liable where they refuse or neglect

40 See: Section 5 - The effectiveness of judicial review of the Recommendation (2004) 20.

41 Recommendation (2003) 16 on the execution of administrative and judicial decisions in the field of administrative law (Committee of Ministers, 9 September, 2003 at the $851^{\text {st }}$ meeting of the Ministers' Deputies). Approached July 232020 https://www.coe.int/en/web/execution/ recommendations.

42 See: Section 1 - Implementation of the Recommendation (2003) 16.

43 Moreover, in urgent cases, the extent of the enforcement procedure should be proportionate to the urgency of the case, so therefore, private persons should be able to lodge an appeal before a judicial authority against the enforcement procedure in order to ensure the protection of their rights and interests. See Section 2 - Enforcement of Recommendation (2003) 16. 
to implement judicial decisions. ${ }^{44}$

\section{CONCLUSION}

The closure of this paper can be defined through the observation that adequate, or proper control over administration implies, primarily, a good legal framework that corresponds to the legal tradition, institutions, as well as the capacities of the state in which it applies. The acceptance of legal solutions by other states that are not adaptable to the internal social and legal order represents a useless application of sources and work. However, adapting to contemporary principles of justice and democracy is an important precondition for the progress of the entire state and society. International legal instruments emerge with the aim of contributing toward the greater protection of rights and the approximation and harmonization of those legal systems that should be an important factor in the process of legislative drafting and other legal acts, as well as their implementation in practice. The judicial review of administrative acts and actions serves two purposes - on one hand, it provides legal protection of individual rights that may be violated by administrative acts or actions, and it simultaneously establishes the possibility of judicial control over the legality of state administrative activity of administrative acts and actions, respectively, as well as ensuring the rule of law, on the other. In this context, it must be emphasized that judicial review of administrative acts can act as a safeguard against abuse and should determine, as a minimum, whether these boundaries and standards have been violated, in contravention of national legislation. Courts and tribunals should possess the necessary power to examine the legal boundaries of the decision-making authority in light of administrative law standards. Within this segment, of particular importance is the interpretation of conventions rights, as well as giving the $\mathrm{COE}$ recommendations a true meaning. The international legal instrument evidently contributes to and exercises impacts regarding the development and advancement of national administrative legislation content, along with the protection and realization of rights and legal interests of individuals in the domain of administrative law by creating international machinery for reviewing the practice of national government administrative systems.

\section{BIBLIOGRAPHY}

1. African Charter on Human and Peoples Rights Nairobi 1981 and entered into force in October 1986. Approached July 232020 https://treaties.un.org/doc/Publication/UNTS/ Volume $\% 201520 /$ volume-1520-I-26363.

2. American Convention on Human Rights "Pact of San Jose, Costa Rica" (b-32), Organization of American States, adopted on 22 November 1969 and entered into force in 18 July 1978. Approached July 232020 https://www.oas.org/dil/treaties_B-32_

44 According to Recommendation (2003) 16, public officials in charge of the implementation of judicial decisions may also be held individually liable in disciplinary, civil or criminal proceedings if they fail to implement them. Additionally, a space in this recommendation is devoted to the obligation of administrative authorities to pay a sum of money and the fact that they should comply with this obligation. 
American_Convention_on_Human Rights_sign.htm,

3. Artico v. Italy, ECHR Application No. 6694/74. Approached July 232020 https://www. dipublico.org/1887/case-of-artico-v-italy-european-court-of-human-rights.

4. Baena-Ricardo et al. v Panama, Inter-American Court of Human Rights, 2 February 2001, para. 124. Approached July 232020 https://www.corteidh.or.cr/docs/casos/ articulos/seriec 72 ing.

5. Casanovas v France, HRC Communication 441/1990, UN Doc CCPR/C/51/D/441/1990, 26 July 1994. Approached July 232020 http://hrlibrary.umn.edu/undocs/html/vws441. htm.

6. Demir and Baykara v. Turkey, ECtHR Application No.34503/97. Approached July 23 $2020 \mathrm{https}: / /$ hudoc.echr.coe.int/tur\#\{\%22itemid\%22:[\%22001-89558\%22]\}.

7. European Convention on Human Rights of 1950, Strasbourg, Council of Europe, approached July 23 2020, https://www.coe.int/en/web/conventions/full-list/-/conventions/ treaty $/ 005$.

8. Feldbrugge v. the Netherlands, ECHR, Application No.8562/79 from 29 May 1986. Approached July 232020 https://opil.ouplaw.com/view/10.1093/law:ihrl/56echr86. case.1/law-ihrl-56echr86.

9. Fortsakis, Theodore. Principles governing good administration, European Public Law 11, no. 2, 2005: 207-217.

10. International Covenant on Civil and Political Rights of 1966 of the United Nations; approached July 232020 https://www.ohchr.org/en/professionalinterest/pages/ccpr.aspx.

11. König v. Germany, ECHR, Application no.6232/73. Approached July 232020 https:// hudoc.echr.coe.int/rus\#\{\%22itemid\%22:[\%22001-57511\%22]\}.

12. Lilić, Stevan. Evropsko upravno pravo, Beograd: Pravni fakultet Univerziteta u Beogradu, 2011.

13. Mollah, Awal Hossain. Judicial Control over Administration and Protect the Citizen's Rights: An Analytical Overview, 2006; https://www.researchgate.net/ publication/320442968.

14. Otočan, Sanja. Analysis of the Current Legal Framework and Case-Law in Respect of Effective Remedies for the Protection of the Right to a Trial within a Reasonable Time in Administrative Procedures and Administrative Disputes, Podgorica, 2019.

15. Puppinck, Grégor. Status of the recommendations of the Committee of Ministers in the legal field of the Council of Europe - Synthesis, Strasbourg: European Centre for Law and Justice, 2012.

16. Recommendation (89) 8 on provisional court protection in administrative matters (adopted by the Committee of Ministers on 13 September 1989 at the $428^{\text {th }}$ meeting of the Ministers" Deputies). Approached July 232020 https://rm.coe.int/16804f288f.

17. Recommendation (91) 1 on administrative sanctions (adopted by the Committee of Ministers on 13 February, 1991 at the $452^{\text {nd }}$ meeting of the ministers' deputies). Approached July 232020 https://rm.coe.int/16804fc94c.

18. Recommendation $\mathrm{CM} / \operatorname{Rec}(2007) 7$ on good administration, approached July 232020 , https://rm.coe.int/16807096b9.

19. Recommendation on the independence, efficiency and role of judges, (adopted by the Committee of Ministers on 13 October, 1994 at the $518^{\text {th }}$ meeting of Ministers' Deputies. Approached July 232020 https:// www.ohchr.org/EN/Issues/Education/Training/Compilation/Pages/12 RecommendationNoR(94)12toMemberStatesontheIndependence,Efficiencyand RoleofJudges(1994).aspx.

20. Recommendation $\operatorname{Rec}(2001) 9$ on alternatives to litigation between administrative authorities and private parties, approached July 23 2020, https://rm.coe.int/16805e2b59. 
21. Recommendation $\operatorname{Rec}(2003) 16$ on the execution of administrative and judicial decisions in the field of administrative law, approached July 23 2020, https://www.coe.int/en/web/ execution/recommendations.

22. Recommendation Rec(2003)17 on enforcement, approached July 23 2020, https://www. coe.int/en/web/cdcj/recommendations-resolutions-guidelines.

23. Recommendation $\operatorname{Rec}(2004) 20$ on judicial review of administrative acts, approached July 23 2020, https://rm.coe.int/CoERMPublicCommonSearchServices/ DisplayDCTMContent?documentId $=09000016805 \mathrm{db} 3 \mathrm{f} 4$.

24. Resolution (77) 31 on protection of the individual in relation to the acts of administrative authorities (Adopted by the Committee of Ministers on 28 September 1977 at the 275th meeting of the Ministers' Deputies). Approached July 232020 https://rm.coe. int/16804dec56.

25. Schmitt, Piere. Access to Justice and International Organizations: The case of Individual Victims of Human Rights Violations, Belgium: Leuven Centre for Global Governance Studies, 2017.

26. Statute of the Council of Europe of 1949, approached July 23 2020, https://www.coe.int/ en/web/conventions/full-list/-/conventions/treaty/001.

27. Universal Declaration of Human Rights of 1948 of the United Nations, approached July 23 2020, https://www.un.org/en/universal-declaration-human-rights/.

28. Weissbrodt, David. The Administration of Justice and Human Rights, University of Hong Kong Law Review, no. 1, 2009: 23-47. 


\section{Blerton Sinani*}

Sažetak

\section{PRISTUP IMPLEMENTACIJI MEĐUNARODNIH PRAVNIH INSTRUMENATA U PODRUČJU KONTROLE NAD UPRAVOM}

U svim zemljama u kojima je prihvaćena vladavina prava uprava je podvrgnuta pravu i nadzoru od strane sudova na istim temeljima kao i pojedinac/građanin, $u$ skladu s principom supremacije prava. Autor prikazuje samo najvažnije instrumente u području međunarodnog prava koji se tiču kontrole nad upravom, koji osiguravaju nadzor nad ostvarenjem zaštite ljudskih prava u zemlji koja je ramificirala dotične instrumente. Stoga ratifikacija i inkorporacija međunarodnih normativnih pravnih instrumenata $\mathrm{u}$ obliku konvencija u nacionalni pravni poredak, poput Europske konvencije o ljudskim pravima, postavlja obvezu državi za poštivanjem ili zaštitom prava garantiranih Konvencijom, kao i presuda Europskog suda za ljudska prava koji se brine o interpretaciji i pravilnoj primjeni Konvencije, relevantnih standarda za procjenu učinkovitosti i uspješnosti javne uprave postavljenih u presudama Europskog suda za ljudska prava. Ove bi presude trebale služiti kao smjernice za poboljšanje pravne regulacije $i$, pod određenim okolnostima, omogućiti izbjegavanje upravnih sporova pred nadležnim domaćim sudovima, ako je to objektivno moguće. Međutim, zbog određenih razloga, koji će biti elaborirani u ovome članku, može doći do devijacija i zbog toga, sudski nadzor znači nadzor od strane upravnih sudova s ciljem osiguranja zakonitosti kao i osiguranja zaštite i ostvarenja prava i pravnih interesa građana u sferi upravnog prava.

Ključne riječi: međunarodno pravo; kontrola; uprava; ljudska prava.

\section{Zusammenfassung}

\section{ANSATZ ZUR UMSETZUNG DER INTERNATIONALEN RECHTSINSTRUMENTE HINSICHTLICH DER ÜBERPRÜFUNG DER VERWALTUNG}

In Einklang mit dem Grundsatz des Vorrangs des Rechts, ist die Verwaltung in allen rechtsstaatlichen Ländern auf gleicher Grundlage wie Einzelpersonen und Bürger dem Recht und Gerichten unterworfen. Der Autor stellt auschlaggebende Instrumente

* Dr. sc. Blerton Sinani, izvanredni profesor, South East European University u Tetovu, Pravni fakultet; blerton.sinani@seeu.edu.mk. 
im Bereich des Völkerrechts in Bezug auf Überprüfung der Verwaltung, welche die Umsetzung der Menschenrechte im Land, das die genannten Instrumente ratifiziert hat, übersieht, dar. Die Ratifizierung und Einführung internationaler Rechtsinstrumente in Form von Konventionen, wie die EMRK, in nationale Rechtssysteme verpflichten den Staat die unter der Konvention gewährleisteten Rechte, sowie die Rechtsprechung des Europäischen Gerichtshofs für Menschenrechte, insbesondere hinsichtlich der Standards für Überprüfung von Effizienz und Wirksamkeit der öffentlichen Verwaltung, zu schützen. Deswegen sollte die Rechtsprechung dazu dienen, die Rechtsvorschriften zu verbessern, sowie, unter bestimmten Umständen, Einleitung Verwaltungsstreitigkeiten vor nationalen Gerichten, falls möglich, zu verhindern. Trotzdem kommt es zu Abweichungen, und gerichtliche Überprüfung bedeute Überprüfung der Verwaltungsakten um ihre Legalität zu gewährleisten und Schutz sowie Verwirklichung von Rechten und Rechtsinteressen der Bürger im Bereich des Verwaltungsrechts zu bieten.

Schlüsselwörter: Völkerrecht; Überprüfung; Verwaltung; Menschenrechte.

Riassunto

\section{UN APPROCCIO ALL'IMPLEMENTAZIONE DEGLI STRUMENTI LEGALI INTERNAZIONALI NELL'AREA DEL CONTROLLO SULL'AMMINISTRAZIONE}

In tutti gli stati governati dal principio di legalità l'amministrazione è soggetta al diritto e alla supervisione dalle corti sulle stesse basi come qualunque individuo/ cittadino, in conformità con il principio della supremazia del diritto. Autore presenta soltanto gli strumenti più importanti nel campo del diritto internazionale relativi al controllo sull'amministrazione, i quali supervisionano l'implementazione dei diritti dell'uomo nel paese che ha ratificato i rispettivi strumenti. Pertanto, la ratificazione e l'incorporazione degli strumenti legali normativi internazionali nella forma di convenzioni, come la Convenzione europea dei diritti dell'uomo all'interno del ordinamento legale nazionale, impone l'obbligo per un certo stato di rispettare o proteggere $\mathrm{i}$ diritti garantiti dalla rispettiva Convenzione, proprio come la giurisprudenza della Corte europea dei diritti dell'uomo determina l'interpretazione e l'appropriata applicazione della Convenzione, la giurisprudenza della rilevante Corte europea dei diritti dell'uomo stabilisce gli standard per valutare l'efficienza e l'effettività della pubblica amministrazione. Quindi, questa giurisprudenza potrebbe fungere da linea guida per il miglioramento delle regolazioni legali e in certe circostanze per evitare l'avvio di un contenzioso amministrativo difronte alle corti nazionali competenti qualora questo sarebbe oggettivamente possibile. Comunque, a causa di certe ragioni che saranno elaborate in questo lavoro, alcune deviazioni possono avvenire, come pure delle revisioni giudiziarie, il che significa una revisione 
dalle corti delle azioni amministrative con una prospettiva sulla garanzia della legalità proprio come fornire la protezione e la realizzazione dei diritti e degli interessi legali dei cittadini nella sfera del diritto amministrativo.

Parole chiave: diritto internazionale; controllo; amministrazione; diritti umani. 
